УДК 1(031)+221

ЦЫРЕНОВ Чингис Цыбикдоржиевич - кандидат исторических наук, научный сотрудник отдела философии, религиоведения и культурологии Института монголоведения, буддологии и тибетологии СО РАН (670047, Россия, Республика Бурятия, г. Улан-Удэ, ул. Сахьяновой, 6; chts17@таil.ru)

\title{
ПАТРИАРХ ЮЖНОКИТАЙСКОГО БУДДИЗМА ХУЭЙЮАНЬ И ГЕНЕРАЛ ВОСТОЧНОЙ ЦЗИНЬ ХУАНЬ СЮАНЬ: ПОЛЕМИКА БУДДИСТА И ДАОСА
}

Аннотация. В статье представлены результаты сравнительного историко-биографического анализа жизнеописаний буддийского патриарха Хуэйюаня (334-416 гг. н.э.) и южнокитайского генерала-аристократа Хуань Сюаня (369-404 гг. н.э.), между которыми развернулась религиозно-философская полемика об истинности идеи воздаяния, а также о необходимости для монахов оказывать почести императору. Оба сочинения («Мин баоин лунь» - «О разьяснении [идеи] воздаяния» и «Шамэнь бу цзин ванчжэ лунь» - «Монахи не должны оказывать почести императору») сыграли важную роль в процессе инкультурации индо-буддийского вероучения в южнокитайский раннесредневековый социокультурный контекст династии Восточная Цзинь (317-420 гг. н.э.). Автор выполнил краткую реконструкцию жизненного пути Хуэйюаня и Хуань Сюаня.

Ключевые слова: ранний китайский буддизм, Восточная Цзинь, китайская буддийская антология «Хун мин цзи»; Хуэйюань, Хуань Сюань, учение о воздаянии

$\Pi$ атриарх южнокитайского буддизма Хуэйюань (мирская фамилия - Цзя) жил и творил в период, когда решалась судьба буддийского учения и буддийской сангхи в китайском обществе. Сведения о жизненном пути Хуэюаня сохранились в буддийском агиографическом сочинении «Жизнеописания достойных монахов» («Гаосэн чжуань»), перевод данного жизнеописания был выполнен видным отечественным китаеведом М.Е. Ермаковым [Ермаков 1994: 202-222]. Сведений о его детстве и юности не так много. Из жизнеописания известно, что он родился в семье потомственного ученого в Северном Китае (уезд Дайсянь, совр. провинция Шэньси), получил блестящее по тем временам традиционное китайское образование и, несмотря на все опасности смутного времени, снискал славу религиозного и политического мыслителя. Прожил он 83 года.

Периоды Троецарствия (220-280 гг. н.э.) и Шести династий (220-589 гг. н.э.), наступившие после крушения империи Восточная Хань (25-220 гг. н.э.) и раскола страны на ряд враждующих между собой эфемерных государственных образований, оказали глубочайшее влияние на массовое сознание всех слоев раннесредневекового китайского общества. Ортодоксальное конфуцианство эпохи Восточной Хань не смогло ответить на вызовы острейшего социальнополитического кризиса китайской государственности, а также полностью удовлетворить духовные, интеллектуальные и экзистенциальные запросы китайского общества той смутной эпохи. Иными словами, в глазах китайской элиты и образованной части китайского общества ханьское конфуцианство временно утратило традиционную «монополию на истину» - исключительное право на непререкаемый авторитет своих норм и традиций. Влияние древнекитайского даосизма, поднятого на щит вождями крестьянского восстания Желтых повязок, также временно пошло на убыль после жесточайшей расправы правительственных войск над восставшими крестьянскими массами. В широкой же социальной среде преобладал религиозный даосизм, опирающийся на древ- 
нюю культовую практику шаманства, магии, предсказаний и народных верований. Особенно это было характерно для областей Южного Китая. Со 2-й половины IV в. значительное, если не главенствующее влияние в духовной жизни приобретает проникший в Китай еще в I в. н.э. буддизм с его свежими и оригинальными идеями индо-буддийской религиозной культуры, концептуального дискурса и системой ценностей. Новым интеллектуальным явлением для поздних этапов Восточной Хань и раннего периода Шести династий стало учение сюаньсюэ («темное», или «сокровенное» учение), которое опиралось на конфуцианские начала, но развивало преимущественно даосские принципы естественности, единения с природой и «недеяния». Буддийский патриарх Хуэйюань, наряду с буддийским проповедником Кумарадживой, был ключевой фигурой китайского буддизма, который смог отстоять автономный статус монашеской общины при южнокитайской династии Восточная Цзинь. Такие попытки подчинить буддийское сообщество государственной власти предпринимала южнокитайская восточноцзиньская аристократия в лице всесильного генерала-южанина, сановного аристократа по имени Хуань Сюань, который после захвата власти на части территории Восточной Цзинь инициировал заочную религиозно-философскую полемику с Хуэйюанем, которая вошла в состав первой раннесредневековой буддийской антологии «Хун мин изи» под названием «Шамэнь бу изин ванчжээ лунь» («Монах не должен оказывать почести вануправителю»)[ Хуэйюань 1993].

Также следует отметить, что 381 г. примечателен другим важным событием: 19-летний император Сяо У-ди официально объявил себя последователем дхармы. С того же времени буддизм стал важным фактором политической жизни Юга [Крюков, Малявин, Софронов 1979: 184]. В связи с этим можно сделать осторожное предположение, что это важное событие связано с приездом и активной проповеднической деятельностью буддиста Хуэйюаня. Со временем Хуэйюань стал властелином дум значительной части южнокитайской аристократии и имперской бюрократии. Так, в частности, в жизнеописании Хуэйюаня сказано, что военный наместник Инь Чжункань лично приезжал в район Лушаньских гор и получил согласие Хуэйюаня на встречу и беседу. Этот эпизод получил свое отражение в сочинении «Новые речения, в мире ходящие» («Ши шо син юй», разд. 4 «Вэньсюэ», эпизод № 61). Всесильный генерал Хуань Сюань также был удостоен личной встречи с лушаньским старцем. Таким образом, монастырь Дунлиньсы стал религиозным центром буддистов Восточной Цзинь. Что же касается столичных храмов и монастырей, то их настоятели и монахи стали активными участниками борьбы придворных группировок.

Биографические сведения о Хуань Сюане дошли до нас в виде жизнеописания, которое вошло в главу 69 раздела «Биографии знаменитых людей» хроники Танского периода под названием «Цзинь шу» (Фан Сюаньлин). В общей сложности Хуэйюань написал 14 произведений, которые частично или полностью вошли в корпус сочинений китайского буддизма под названием «Да изан изин». Краткий анализ основных сочинений можно найти в публикации Ю.К. Щуцкого [Шуцкий 2006]. Хуэйюань почитается в буддийской школе Цзинту (Чистая земля) как ее родоначальник. Он известен как старший Хуэйюань, в отличие от младшего Хуэйюаня - буддийского монаха династии Суй (581-618 гг.), при которой Северный и Южный Китай был собран под началом одного правящего дома.

Следует сказать, что в Южном Китае буддийские монахи уже были при дворе правителей царства У, которое было завоевано северной династией Западная Цзинь (265-317) в 280 г. Но при этом позиции буддизма в Южном Китае только начинали укрепляться. Позже, при Восточной Цзинь, буддийские монахи по- 
степенно получили поддержку южного аристократического клана Хэ, который стремился подмять всю власть в столице под себя и отстранить от трона пришлых северных аристократов (клан Юй). Следующий южный родовитый клан Хуань в лице генерала Хуань Сюаня, набравший силу на окраинах Восточной Цзинь, предпринял неудачную попытку подчинить буддистов и тем самым пополнить податные списки за счет возвращения множества крестьян, укрывшихся в буддийских монастырях от сборщиков налогов.

Что касается сочинения «Мин баоин лунь» («О разъяснении [идеи] воздаяния»), то оно дошло до нас в составе самой ранней антологии текстов китайского буддизма под названием «Хунминизи» («Собрание сочинений, светоч истины распространяющих»), которая была составлена в 515-518 гг. н.э. придворным буддистом-историографом по имени Сэнъю ${ }^{1}$ (445-518 гг. н.э.) после знаменитой полемики 508-509 гг. о бессмертии души при дворе императора южнокитайской династии Лян по имени У-ди. Данный факт объясняется тем, что в период династии Лян буддизм фактически стал государственной религией, и, соответственно, число буддийских сочинений многократно увеличилось.

В данном сочинении приведены три вопроса Хуань Сюаня, адресованных Хуэйюаню, которые касались буддийской концепции воздаяния. Суть этих вопросов сводилась к тому, что Хуань Сюань отрицал сам факт возмездия за зло, т.к., по его мнению, эмоции (симпатии и антипатии) и эгоистические устремления, которые являются причиной совершения зла, заложены в человеке самой природой. Отсюда Хуань Сюань делал вывод о неправомерности буддийского тезиса о воздаянии за убийство живых существ. Кроме того, при убийстве живого существа, по Хуань Сюаню, страдает только оболочка души, сама же душа не ощущает никакой боли, т.е. душа и телесная оболочка интерпретировались как автономные части. Для подкрепления своих философских рассуждений Хуань Сюань воспользовался индо-буддийским натурфилософским учением о Четырех великих основах (Земля, Вода, Огонь и Ветер), которые образуют весь мир и являются первоосновой телесной оболочки всех живых существ. Очевидно, таким образом Хуань Сюань искал оправдание своим преступным действиям. В ответ на доводы Хуань Сюаня Хуэйюань писал, что людские пороки, порождающие зло, обусловлены неведением (авидьей) еще до того, как души обретают телесную оболочку. А задача человека заключается в том, чтобы избавиться от этих заблуждений (неведения и желания) и тем самым избежать неблагого воздаяния.

Ради убеждения своих оппонентов из числа даосов и конфуцианцев в истинности буддийских религиозно-философских постулатов Хуэйюань, будучи буддистом, все же использовал яркие метафоры из даосского трактата «Чжуанизы». Судя по всему, изящный слог и даосская риторика оказала свое воздействие на южанина Хуань Сюаня.

Из жизнеописания Хуань Сюаня известно, что в плане религиозных предпочтений он был сторонником даосизма, особенно это касалось даосских магических и предсказательных практик. Поэтому изначально Хуань Сюань стремился ограничить растущее влияние буддизма. После того как Хуань Сюань разделался с ненавистным царедворцем Сыма Даоцзы и сыном Сыма Юаньсянем, а также после вступления в столичный город Цзянькан он приказал всем монахам оказать ему почести, положенные правителю (вану). По этому поводу Хуань Сюань вел ожесточенную полемику со столичным сановником Ван Ми, буддистом по вероисповеданию. После провозглашения себя Чусским ваном Хуань Сюань

\footnotetext{
1 Сэнъю (445-518 гг. н.э.) - придворный историограф-буддист при династиях Ци (479-502 гг. н.э.) и Лян (после 502-557 гг. н.э.).
} 
издал еще больше антибуддийских указов. Но после того как Хуань Сюань стал императором, его политика в отношении буддистов резко изменилась. Такие перемены были продиктованы стремлением Хуань Сюаня получить поддержку южнокитайского буддийского сообщества.

Что касается умонастроений народных низов юго-восточного региона Китая, то здесь следует сказать о самом масштабном и продолжительном крестьянском восстании периода Восточной Цзинь под эгидой южан Сунь Тая, Сунь Эня и Лу Сюня, которые поочередно возглавляли даосскую секту «Пять ковшей риса» $(y$ доу ми дао), направленную против гнета правящего класса династии Восточная Цзинь. В 399 г. в ответ на арест и казнь даосского лидера Сунь Тая его племянник Сунь Энь поднял население юго-восточных прибрежных районов против царствующей династии и ее 10-го императора Ань-ди (Сыма Дэцзун), который, согласно историческим хроникам, был умственно неполноценным и недееспособным человеком. Реальная власть в империи была в руках младшего 12-летнего брата императора по имени Сыма Дэвэнь (впоследствии он стал императором, но был задушен в возрасте 20 лет), регентов и генерала-аристократа Хуань Сюаня. На начальных этапах восстания войска Сунь Эня успешно расширяли зону своего контроля. Затем правительственные войска, а именно войска Северного военного управления (бэй-фу бин) под командованием Лю Юя, постепенно начали оттеснять повстанцев к морскому побережью. В результате Сунь Энь покончил с собой, а новым вождем восставших стал Лу Сюнь, отец которого в молодости изучал буддийское учение вместе с Хуэйюанем и был с ним в хороших отношениях. По этой причине Лу Сюнь еще до разгрома своей повстанческой армии прибыл к подножию горного монастыря Лушань и просил Хуэйюаня о личной встрече. Очевидно, что согласие встретиться с повстанцем могло бросить тень на самого иерарха, и люди из окружения отговаривали Хуэйюаня от этого решения. Но, тем не менее, Хуэйюань принял решение встретить Лу Сюня, и они уединились на достаточно долгое время в монастыре. Как оказалось, после подавления восстания эпизод приема вождя повстанцев никак не повлиял на хорошие отношения Хуэйюаня с императорским двором. Это дает основание утверждать, что наряду с буддизмом в народных низах были довольно популярны и даосские верования, особенно это касается юго-восточных прибрежных районов Восточной Цзинь.

Важно отметить также, что в 402 г. 70-летний Хуэйюань основал в горном монастыре Дунлиньсы «Общество белого лотоса» (Бай лянь шэ), куда были допущены только аристократы, избранные самим Хуэйюанем. Во время торжественной церемонии основания этого общества Хуэйюань вместе с избранными учениками из аристократов принял коллективный обет переродиться в буддийских Чистых землях, а также торжественно высадил специально подготовленные белые лотосы в заблаговременно подготовленный горный пруд. Данный факт еще раз подтверждает тезис о том, что в конце Восточной Цзинь буддизм занимал довольно прочные позиции в политике и экономике Южного Китая.

Все изложенное выше дает основание сделать следующие выводы.

Во-первых, установлено, что южнокитайское буддийское духовенство в лице Хуэйюаня, несмотря на все опасности водоворота придворных интриг, смогло сохранить и преумножить культурно-символический капитал китайского буддизма, снискал симпатии южных и северных аристократических и худородных придворных кланов и тем самым внес значительный вклад в процесс развития и адаптации буддийского учения в южнокитайской культурной среде. Главными факторами успеха Хуэйюаня стали его личные качества (талант, харизма, эрудиция), утрата конфуцианством монополии на истину, а также общий кризис имперской бюрократии, характерный для эпохи раздоров и смуты. 
Во-вторых, установлено, что могущественный южный аристократ и противник буддизма Хуань Сюань, который вынашивал планы свержения династии Восточная Цзинь, совсем недолго продержался на горизонте китайской истории, хотя имел определенные шансы на победу над худородным генералом Лю Юем. Антибуддийские взгляды грозного южного аристократа Хуань Сюаня говорят о том, что южная знать в его лице стремилась подчинить буддийскую сангху имперской власти, тогда как набиравший силу худородный южный клан генерала Лю Юя был настроен менее воинственно в отношении буддийского сообщества. Главными причинами его поражения был целый ряд военно-политических просчетов, чрезмерная жестокость по отношению к своим подданным, а также общий острый и глубокий кризис, охвативший как южную, так северную знать. Хуань Сюань был продуктом политической эволюции изжившей себя китайской аристократии эпохи смут и нестабильности. На смену этой прослойке на арену южнокитайской истории вышли военные лидеры из простолюдинов, которые основали следующую династию - Лю Сун - и сформировали новую аристократию.

B-третьих, в рамках изложения индо-буддийского дискурса по проблеме воздаяния Хуэйюань смог на основе традиционного китайского учения о макрокосмическом резонансе стимулов и реакций (гань-ин) заложить основу для развития плодотворного концептуального дискурса о воздаянии и судьбе в раннем китайском буддизме. Судьба аристократа Хуань Сюаня подтвердила истинность буддийского учения о воздаянии. Аристократ Хуань Сюань, будучи жертвой двух главных сил сансары - неведения (авидья) и алчности (тришна), пролил немало крови простых беззащитных людей, а также своих конкурентов по сословию аристократов ради удовлетворения своих неуемных личных и политических амбиций и искренне надеялся на то, что не получит никакого возмездия за свои действия.

Статья подготовленав вамкахгосударственного задания России (проект ХII.191.1.3. "Комплексное исследование религиознофилософских, историко-культурных, социально-политических аспектов буддизма в традиционных и современных контекстах России и стран Центральной и Восточной Азии», номер госрегистрации № АAAA-A17-117021310263-7).

\section{Список литературы}

Ермаков М.Е. 1994. Мир китайского буддизма. СПб: Изд-во «Андреев и сыновья». $240 \mathrm{c.}$.

Крюков М.В., Малявин В.В., Софронов М.В. 1979. Китайский этнос на пороге средних веков. М.: Наука. 328 с.

Хуэйюань. 1993. Монах не должен оказывать почести императору (пер. с кит. А.С. Мартынова). - Буддизм в переводах: альманах. Вып. 2. СПб. С. 179-191.

Щуцкий Ю.К. 2006. Даос в буддизме. - Религиозный мир Китая 2005. Исследования, материалы, переводы (под ред. И.С. Смирнова). Вып. ІХ. М.: Изд-во ИВКА РГГУ. С. 166-180. 
TSYRENOV Chinghis Tsybikdorzhievich, Cand.Sci. (Hist.), Researcher of the Department of Philosophy, Religion and Culturology, Institute for Mongolian, Buddhist and Tibetan Studies, Siberian Branch of Russian Academy of Sciences (6 Sakhyanovoj St, Ulan-Ude, Republic of Buryatia, Russia, 670047; chts17@mail.ru)

\section{THE PATRIARCH OF SOUTHERN CHINESE BUDDHISM HUIYUAN AND GENERAL, THE EASTERN JIN DYNASTY HUAN XUAN: THE CONTROVERSY OF BUDDHIST AND TAOIST}

Abstract. The article presents the results of a comparative historic-biographical analysis of biographies of the buddhist patriarch Huiyuan (334-416 AD) and the South Chinese general-aristocrat Huan Xuan (369-404 AD), between which the religious-philosophical controversy about the truth of the idea of retribution and about the necessity for monks to honor the emperor took place. The author clarifies that both writings ("Min Baoin Lun» - "On Clarifying [the idea] of Retribution" and "Shamen bu jing wangzhe lun» - «Monks Should not Honor the Emperor») played an important role in the process of enculturation of Indo-Buddhist dogma in the South Chinese early medieval socio-cultural context of the Eastern Jin dynasty (371-420 AD). The author also made a brief reconstruction of the life path of Huiyuan and Huan Xuan.

Keywords: early Chinese Buddhism, Eastern Jin (317-420 AD), Chinese Buddhist anthology «Hong ming ji», Huiyuan, Huan Xuan, doctrine of retribution 